\title{
Topology of Pretreated Wood Fibers Using Dynamic Nuclear Polarization
}

\author{
Viger-Gravel, Jasmine; Lan, Wu; Pinon, Arthur César; Berruyer, Pierrick; Emsley, Lyndon; Bardet, \\ Michel; Luterbacher, Jeremy
}

Published in:

Journal of Physical Chemistry C

Link to article, DOI:

10.1021/acs.jpcc.9b09272

Publication date:

2019

Document Version

Peer reviewed version

Link back to DTU Orbit

Citation (APA):

Viger-Gravel, J., Lan, W., Pinon, A. C., Berruyer, P., Emsley, L., Bardet, M., \& Luterbacher, J. (2019). Topology of Pretreated Wood Fibers Using Dynamic Nuclear Polarization. Journal of Physical Chemistry C, 123(50), 30407-30415. https://doi.org/10.1021/acs.jpcc.9b09272

\section{General rights}

Copyright and moral rights for the publications made accessible in the public portal are retained by the authors and/or other copyright owners and it is a condition of accessing publications that users recognise and abide by the legal requirements associated with these rights.

- Users may download and print one copy of any publication from the public portal for the purpose of private study or research.

- You may not further distribute the material or use it for any profit-making activity or commercial gain

- You may freely distribute the URL identifying the publication in the public portal 


\title{
Topology of Pretreated Wood Fibers using Dynamic Nuclear Polariza- tion
}

\author{
Jasmine Viger-Gravel, ${ }^{\dagger}$ Wu Lan,${ }^{\dagger}$ Arthur C. Pinon, ${ }^{\dagger,+}$ Pierrick Berruyer,${ }^{\dagger}$ Lyndon Emsley, ${ }^{\dagger}$ Michel Bar- \\ det, ${ }^{\dagger}, \|^{*}$ Jeremy Luterbacher ${ }^{\dagger *}$
}

$\dagger$ Institut des Sciences et Ingénierie Chimiques, Ecole Polytechnique Fédérale de Lausanne (EPFL), CH-1015 Lausanne, Switzerland. * Department of Electrical Engineering, Center for Hyperpolarization in Magnetic Resonance, Technical University of Denmark, Building 349, DK-2800 Kgs Lyngby, Denmark "Université Grenoble Alpes, CEA, IRIG-MEM, Laboratoire de Résonance Magnétique, Grenoble, 38000, France.

NMR, DNP SENS, poplar wood, cellulose, lignin, chemical process, depolymerization

\begin{abstract}
In the continuously developing field of lignocellulosic biomass, high-yield lignin depolymerization processes are sought to optimize its productivity and profitability. Recently, formaldehyde stabilization during lignin extraction and biomass pretreatment has been found to drastically enhance subsequent lignin upgradeability but can affect cellulose digestibility. The exact role and/or form of formaldehyde on the residual biomass surface is still not fully understood. Here, we use magic angle spinning (MAS) dynamic nuclear polarization (DNP) methods to characterize the components that remain inside the residual cell wall after the lignin extraction process and reveal the topochemistry of the solid residue. The regioselectivity of relayed DNP allows the observation of hyperpolarization in a range of 40 to $200 \mathrm{~nm}$ from the surface of the cell wall for poplar wood materials. That regioselectivity allows us to distinguish between the external secondary cell wall and the inner middle lamellae. In that respect, for the untreated wood, we confirm that there is less lignin in the outer part of the cell wall than deeper inside. In treated wood we determine that the role of dioxane during the process is to enable the extraction of the modified products from the cell wall. We show that the modified lignins which were not extracted in the absence of dioxane accumulate in a $40 \mathrm{~nm}$ region at the surface of the cell wall. Also, using carbon13 enriched formaldehyde during the process we show that $1 \%$ of the total amount of carbon in the material is assigned to selfpolymerization and that no covalent bonds to cellulose are observed.
\end{abstract}

\section{INTRODUCTION}

Pretreatment (or delignification) is a key process in biorefineries and pulp and paper processes that facilitates integrated biomass utilization. This step fractionates the biomass into its three major components, cellulose, hemicelluloses, and lignin (see chemical structures in Scheme 1), facilitating downstream process with the objective of converting each component into value-added products. ${ }^{1-4}$ Recently, a lignin extraction process using aliphatic aldehydes was developed that leads to in situ stabilization of the lignin structure during acid pretreatment, leaving behind a high purity cellulose-rich solid. ${ }^{5-7}$ Despite its purity, this leftover solid, still needed further acid treatment before enzymatic hydrolysis to release high yields of glucose when formaldehyde was used. The exceptional purity of the cellulose after treatment was thought to be due to the excellent solubilization of stabilized lignin in the chosen solvent system, which avoided re-condensation or re-deposition of the lignin on the solid surface. The reason for the need for an additional acid treatment was thought to be a reaction between the formaldehyde and the hydroxyl on the cellulose surface, which could have prevented reaction between the cellulose and enzyme.
However, no direct evidence showed that formaldehyde did react with the cellulose. ${ }^{5}$ Here, we use magic angle spinning dynamic nuclear polarization (MAS DNP) NMR spectroscopy methods to illustrate the delignification process, reveal the topochemistry of the solid residue, and elucidate the exact nature of the components that remain inside the residual cell wall after the fractionation process.

High-resolution liquid-state NMR of either ${ }^{1} \mathrm{H}$ or ${ }^{13} \mathrm{C}$ have been used in this area for several decades and have provided data to elucidate the main polymer components of wood to better understand the chemistry and biochemistry of plant cell walls. ${ }^{8-14}$ However, the acquisition of NMR spectra in solution requires the extraction of the key components, which leads to chemical modifications, and, by nature, destroys the spatial arrangement of the constituents. Gel-state NMR methods were developed to characterize whole cell wall biomass non-destructively but these methods require extensive preparation and cannot provide information on the surface functionalities of the biomass. ${ }^{15,16}$ To circumvent this, high-resolution solid-state NMR has become the method of choice for the study of unmodified lignocellulosic samples, allowing the determination of the three-dimensional structure of polymers and their spatial localization 
inside cell walls, notably with high-resolution magic angle spinning (MAS) solid state ${ }^{13} \mathrm{C}$ NMR experiments. ${ }^{17-26}$

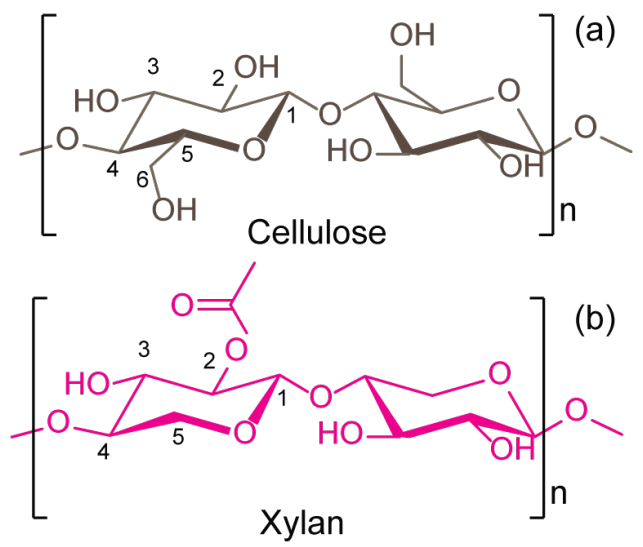

(c)

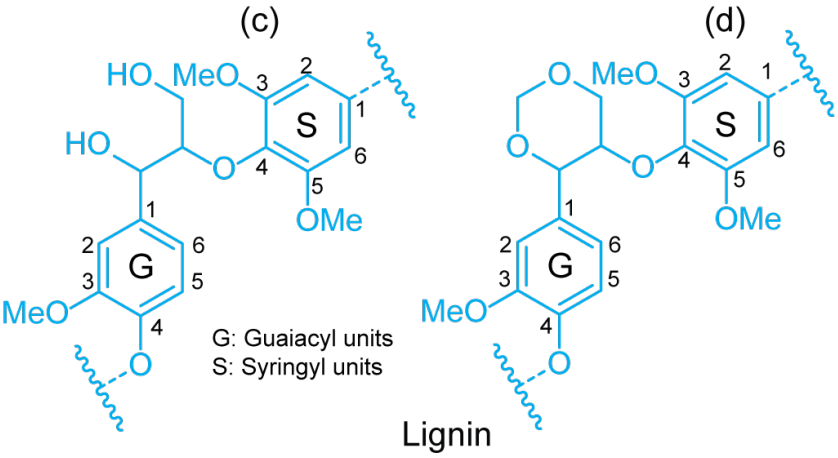

Scheme 1. Molecular structure of (a) cellulose, (b) Xylan, the most abundant chemical component of hemicellulose (the acetates are randomly distributed on the hemicelluloses and so do not necessarily repeat regularly), (c) lignin, and (d) formaldehyde stabilized lignin.

While detailed structural studies using multi-dimensional NMR often previously required ${ }^{13} \mathrm{C}$ enriched samples, the recent advent of Dynamic Nuclear Polarization (DNP) ${ }^{27}$ methods for MAS NMR of materials ${ }^{28,29}$ have allowed the study of a wide variety of materials at natural isotopic abundance such as functionalized surfaces,${ }^{28-31}$ nanoparticles, ${ }^{32,} 33$ inorganic solids, ${ }^{34,35}$ polymers $^{36-49}$ or biomolecules. ${ }^{50-55}$ MAS DNP techniques have also been recently applied to isolated celluloses, cellulose derivatives in pharmaceutical formulations, ${ }^{56-59}$ modified lignocellulosic biomass and functionalized paper substrates at natural abundance. ${ }^{19,60-63}$

MAS DNP experiments are usually carried out on powdered samples using the incipient wetness impregnation (IWI) technique, ${ }^{28,29}$ which requires doping the sample with a source of unpaired electrons by impregnating the dry powder with a radical solution. The source of unpaired electrons is usually a solution containing a stable radical. The radicals most widely used today for cross effect DNP (currently the most efficient DNP mechanism at moderate magnetic field, e.g. 9.4 T, and at temperatures $\sim 100 \mathrm{~K}$ ), include AMUPol, ${ }^{64}$ TOTAPOL $^{65}$ or TEKPol. ${ }^{66,67}$ Irradiation of the NMR sample with microwaves to saturate the EPR transition of the unpaired electron can lead to spontaneous transfer of polarization from the electrons to the nearby nuclear spins, usually the protons of the frozen solvent.
The polarization is then further transferred to heteronuclei by cross polarization $^{68}(\mathrm{CP})$ experiments.

NMR can also be used to probe domain sizes in heterogeneous solids. ${ }^{69,70}$ In MAS DNP experiments ${ }^{1} \mathrm{H}-{ }^{1} \mathrm{H}$ spin diffusion usually distributes the proton hyperpolarization throughout the entire nuclear spin bath. We have recently shown how the dynamics of hyperpolarization in relayed-DNP experiments can be analysed in terms of a polarization diffusion model to very efficiently extract domain sizes in active pharmaceuticals ingredients, microcrystalline solids and polymer blends. ${ }^{71-73}$ Also, it is possible to measure the distance that polarization travels (from micro meter to $\mathrm{nm}$ scales), and determine layer structures, which has been shown in the case of organic crystalline nanoparticles ${ }^{74}$ and lipid nanoparticle based drug delivery systems. ${ }^{75}$

Here, we characterize the transformations of poplar wood after different fractionation processes using relayed MAS DNP methods. We determine (i) the influence of the duration of the chemical treatment on the residual lignins; (ii) the role of dioxane and formaldehyde during chemical treatment; and (iii) that relayed DNP methods are regioselective towards the cell wall and distinguish the location of the residual lignins.

\section{EXPERIMENTAL METHODS}

\subsection{Wood sample preparation}

A transgenic plant, ferulate 5-hydroxylase down-regulated poplar, was used as the wood sample in order to provide easily upgradeable and highly uniform lignin. Indeed, past studies have shown this lignin to be upgradeable at high yields $(\sim 80 \%)$ and feature almost exclusively syringyl units $(>98 \%$, see structure in Scheme 1). ${ }^{5,6}$ The sample was ball-milled into fine particles for 1 h using a PM100 planetary ball mill machine (Retsch, German) at $450 \mathrm{rpm}$. The ball-milled wood was placed in a thick wall glass reactor together with $9 \mathrm{~mL}$ of dioxane, $0.42 \mathrm{~mL}$ of $37 \% \mathrm{HCl}$, and $1 \mathrm{~mL}$ a $36 \mathrm{wt} \%$ formaldehyde solution. The reactor was sealed tightly and placed in an oil bath at $80{ }^{\circ} \mathrm{C}$ for 0.5 to $2 \mathrm{~h}$ under continuous stirring. After the reaction, the mixture was filtered and the solid was washed with dioxane $(3 \times 5$ $\mathrm{mL}$ ). The residue was dried at $100^{\circ} \mathrm{C}$ for $15 \mathrm{~h}$. In the case where formaldehyde was not added during pretreatment, an extra 0.69 $\mathrm{mL} \mathrm{H}_{2} \mathrm{O}$ was added to the reaction mixture. In the case where dioxane was not used during pretreatment, $10 \mathrm{~mL}$ of $\mathrm{H}_{2} \mathrm{O}$ and $0.42 \mathrm{~mL}$ of $37 \% \mathrm{HCl}$ were added instead of the aforementioned solution.

\subsection{DNP Experiments.}

DNP experiments were performed on a $263 \mathrm{GHz} / 400 \mathrm{MHz}$ AVANCE III Bruker DNP system. The spectrometer is equipped with a low temperature CPMAS probe and a $263 \mathrm{GHz}$ gyrotron capable of outputting ca. 5-10 W of CW microwaves. The probe was configured in ${ }^{1} \mathrm{H} /{ }^{13} \mathrm{C}$ double mode. The sweep coil of the main magnetic field was optimized so that microwave irradiation gave the maximum positive proton DNP enhancement for AMUPol. DNP enhancements were determined by comparing the intensity of the spectra acquired with and 
without microwave irradiation, and the ${ }^{1} \mathrm{H}$ and ${ }^{13} \mathrm{C}$ enhancements are tabulated in the supplementary information (SI) for all samples studied.

Note that all samples were ball milled at moderate conditions to maintain some fiber structure (as described above), and further ground in a mortar and pestle to obtain a homogeneous material before proceeding to DNP sample preparation.

For DNP experiments, typically $30 \mathrm{mg}$ of ground wood sample was impregnated with $16 \mu \mathrm{l}$ of $10 \mathrm{mM}$ AMUPol in $\mathrm{D}_{2} \mathrm{O} / \mathrm{H}_{2} \mathrm{O}$ $(9 / 1 \mathrm{v} / \mathrm{v})$. The DNP sample was then packed in a $3.2 \mathrm{~mm}$ sapphire rotor and capped with a Teflon plug and zirconia cap. The filled DNP rotor was then spun at room temperature in the spinning station up to $12.5 \mathrm{kHz}$ before being inserted into the precooled (ca. $100 \mathrm{~K}$ ) $3.2 \mathrm{~mm}$ CPMAS DNP NMR probe, where the sample was frozen within several seconds.

DNP enhanced ${ }^{1} \mathbf{H}$ and ${ }^{13} \mathbf{C}$ Solid-State NMR. For ${ }^{13} \mathrm{C}$ NMR experiments, the recycle delays were 3 or $4 \mathrm{~s}$. The ${ }^{1} \mathrm{H} \pi / 2$ pulse length used for the variable amplitude CP experiments was 2.5 $\mu$ s to afford $100 \mathrm{kHz}{ }^{1} \mathrm{H}$ decoupling using SPINAL-64. ${ }^{76}$ The MAS frequency used is $12.5 \mathrm{kHz}$.

\section{RESULTS AND DISCUSSION}

3.1. ${ }^{13} \mathrm{C}$ NMR and DNP enhanced NMR features of un-treated fibers. Figure $1 \mathrm{~A}-\mathrm{B}$ shows the conventional ${ }^{13} \mathrm{C}$ CPMAS NMR spectra of un-treated poplar wood recorded at room temperature (A), and at $100 \mathrm{~K}$ (B). Spectra A and B were acquired without DNP. Figure $1 \mathrm{C}$ shows the DNP enhanced ${ }^{13} \mathrm{C}$ CPMAS NMR spectrum of poplar wood impregnated with $10 \mathrm{mM}$ AMUPol in $\mathrm{D}_{2} \mathrm{O} / \mathrm{H}_{2} \mathrm{O} 9 / 1 \mathrm{v} / \mathrm{v}$. The room temperature spectrum $\mathrm{A}$ is typical of lignocellulose and compares with all the data previously published. ${ }^{8,9,77-80}$

Full assignment of the main signals are shown in Figure 1 (chemical shifts are tabulated in SI) and follow previous assignments of this type of material. ${ }^{77,81}$ The identification of the main ${ }^{13} \mathrm{C}$ NMR resonances is important in order to follow the chemical changes of lignocellulosic materials during chemical and thermal treatment. The resonance at $21 \mathrm{ppm}$ is assigned to the $\mathrm{CH}_{3}$ carbons of the hemicelluloses acetate units. In the interval ranging between 60 and 105 ppm, large signals prevail which are predominantly assigned to cellulose, and to a lesser extent to hemicellulose carbohydrates. Of particular interest are the signals at $88.3 \mathrm{ppm}$ and $82.8 \mathrm{ppm}$, assigned to the $\mathrm{C} 4$ of cellulose allomorphs. The signal at $82.8 \mathrm{ppm}$ is indicative of either amorphous or disordered cellulose at the surface of crystalline microfibers, whereas the signal at $88.3 \mathrm{ppm}$ refers to crystalline cellulose. $^{81}$

These signals overlap with the aliphatic carbons of lignins. In this area, the only resonance which can be specifically assigned to lignins is at $55.8 \mathrm{ppm}$, due to methoxy groups occurring in aromatic units. The intense signal $104.8 \mathrm{ppm}$ is assigned to the $\mathrm{C} 1$ of cellulose, although some overlap with aromatic carbons of lignins cannot be excluded. A broad and weak shoulder centred at 102 ppm can be assigned to the $\mathrm{C} 1$ of hemicelluloses, the broadness of this signal being clearly assigned to the amorphous structure. The peaks occurring in the region between $105 \mathrm{ppm}$ and $160 \mathrm{ppm}$ are specific to carbons from the aromatic units of lignins. For hardwood, the presence of syringyl units is identified by the signal at 152.6 ppm classically assigned to C3 and $\mathrm{C} 5$ on the aromatic ring. On the low-frequency side of the previous signal, the shoulder is mainly assigned to the same carbons, but in non-etherified structures. Signal at $151.7 \mathrm{ppm}$ is assigned to $\mathrm{C} 1$ and signal at 148.4 can be assigned to $\mathrm{C} 4$ and C3 in guaiacyl units. The latter signal is quite week, which is due to the low amounts of guaiacyl units in this type of transgenic poplar $(<2 \%) .^{5}$ The shoulder at $144.1 \mathrm{ppm}$ corresponds to $\mathrm{C} 4$ in non-etherified structures. The relative intensities of these two broad signals allow us to estimate the depletion of the lignin polymers in biomass materials. The signal at $172.6 \mathrm{ppm}$, is generated by the carbonyls of hemicelluloses acetate groups.

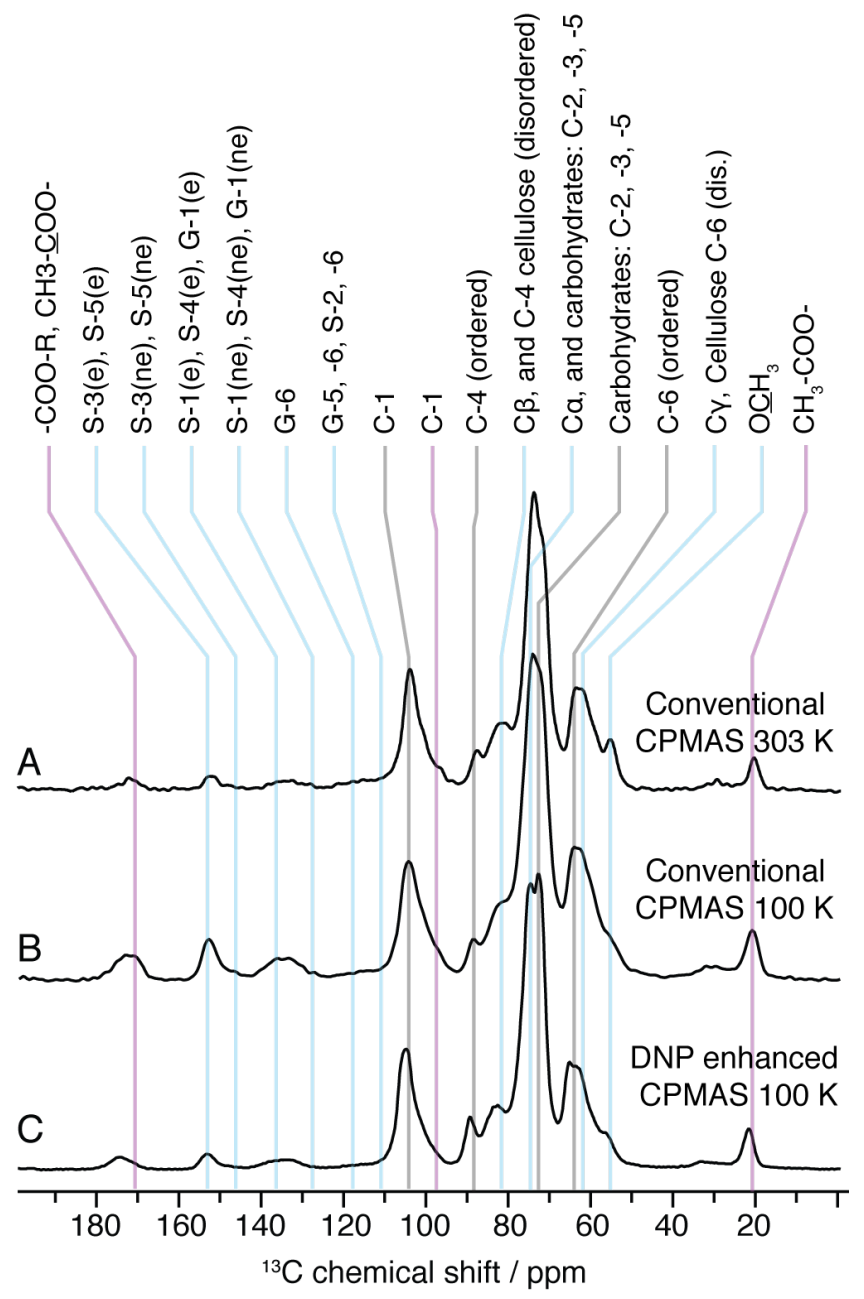

Figure 1. ${ }^{13} \mathrm{C}$ CPMAS NMR spectra of untreated poplar wood acquired at: (A) room temperature, 16384 scans, 3 s recycle delay, 1 ms contact time, $12.5 \mathrm{kHz}$ spinning rate; (B) at $100 \mathrm{~K}, 15230$ scans, $3 \mathrm{~s}$ recycle delay, $1 \mathrm{~ms}$ contact time, $12.5 \mathrm{kHz}$ spinning rate. (C) ${ }^{13} \mathrm{C}$ CPMAS DNP enhanced NMR spectrum at $100 \mathrm{~K}$, sample is impregnated with $10 \mathrm{mM}$ AMUPol in $\mathrm{D}_{2} \mathrm{O} / \mathrm{H}_{2} \mathrm{O}(9 / 1 \mathrm{v} / \mathrm{v}) 224$ scans, $3 \mathrm{~s}$ recycle delay, $2 \mathrm{~ms}$ contact time, $12.5 \mathrm{~Hz}$ spinning rate. The assignment of the resonances follows the color code of the molecular structure of cellulose (black), hemicellulose (purple), and lignin (blue) described in scheme 1 and abbreviations; ne is for non- 
etherified arylglycerol $\beta$-aryl ethers, and e: in etherified arylglycerol $\beta$-aryl ethers (see SI for table of chemical shifts).

Although the three spectra A, B and C were recorded under optimized experimental conditions, some differences are noticed. The first is a slight loss of resolution of the spectra recorded at low temperature (B and $\mathrm{C}$ ) compared to the one recorded at room temperature (Spectrum A). This is particularly visible for the signal of lignin methoxy and for the $\mathrm{C} 4$ of disordered celluloses and hemicelluloses. This is due to lignins and hemicelluloses being amorphous and therefore when their molecular dynamics become restrained at low temperatures an increase in the NMR line widths is expected. ${ }^{82}$ At low temperature, the lignin and hemicellulose become more rigid which explains an increase in their signal intensity for those regions of the spectra as $\mathrm{CP}$ will be more efficient.

As shown in the SI and summarized in Table S3, we compare the overall signal to noise ratio (SNR) of the DNP enhanced spectra to the conventional SSNMR spectra $^{83}$ for untreated wood sample recorded at room temperature (RT) and at $100 \mathrm{~K}$ (both recorded on a dry powder without the addition of AMUPol solution). The ${ }^{13} \mathrm{C}$ SNR of the DNP enhanced spectra (acquired with microwave irradiation on) are 10 times that acquired without DNP at RT and 6 times higher than the spectrum acquired at $100 \mathrm{~K}$, which represent a gain in experimental time of a factor 100 and 36, respectively. (The increase in intensity of the NMR signals observed at low temperature is expected and due to the Boltzmann factor.) Note that for the lignins and hemicelluloses, the gain in intensity is even larger, a factor 14 and 12, respectively, (see SI TableS3).

3.2. Lignin extraction. Pretreatment (or delignification) is a common process in biorefineries and pulp and the paper making industry. In a laboratory-scale method, lignin can be largely extracted using polar aprotic solvents such as dioxane under acidic conditions and elevated temperatures $\left(>80^{\circ} \mathrm{C}\right)$. We can use DNP enhanced NMR to follow the extent lignin extraction and the effect of the various pretreatment parameters on the biomass surface functionalities.

Figure 2 shows the ${ }^{13} \mathrm{C}$ CPMAS DNP enhanced NMR spectra of untreated poplar wood (F), as well as poplar wood after lignin extraction under acidic conditions with a dioxane $/ \mathrm{H}_{2} \mathrm{O} /$ formaldehyde solution for $30 \mathrm{~min}$ (E) or $2 \mathrm{~h}$ (D). The samples are all subsequently impregnated with $10 \mathrm{mM}$ AMUPol in water $\left(\mathrm{D}_{2} \mathrm{O} / \mathrm{H}_{2} \mathrm{O} 9 / 1 \mathrm{v} / \mathrm{v}\right)$. Scheme 2 illustrates a transverse section on the micrometer scale of the wood cell wall. We expect the radical solution to impregnate the cell lumen (CL) which is located at the exterior of the cell wall, and to also wet the layers of the secondary cell wall L3 and L2 (black and grey). The relative proportions of the three wood polymers (celluloses, hemicelluloses and lignins) vary depending on the part of the cell wall. It is known that a greater concentration of lignins and hemicellulose are present in the middle lamella regions. ${ }^{84}$

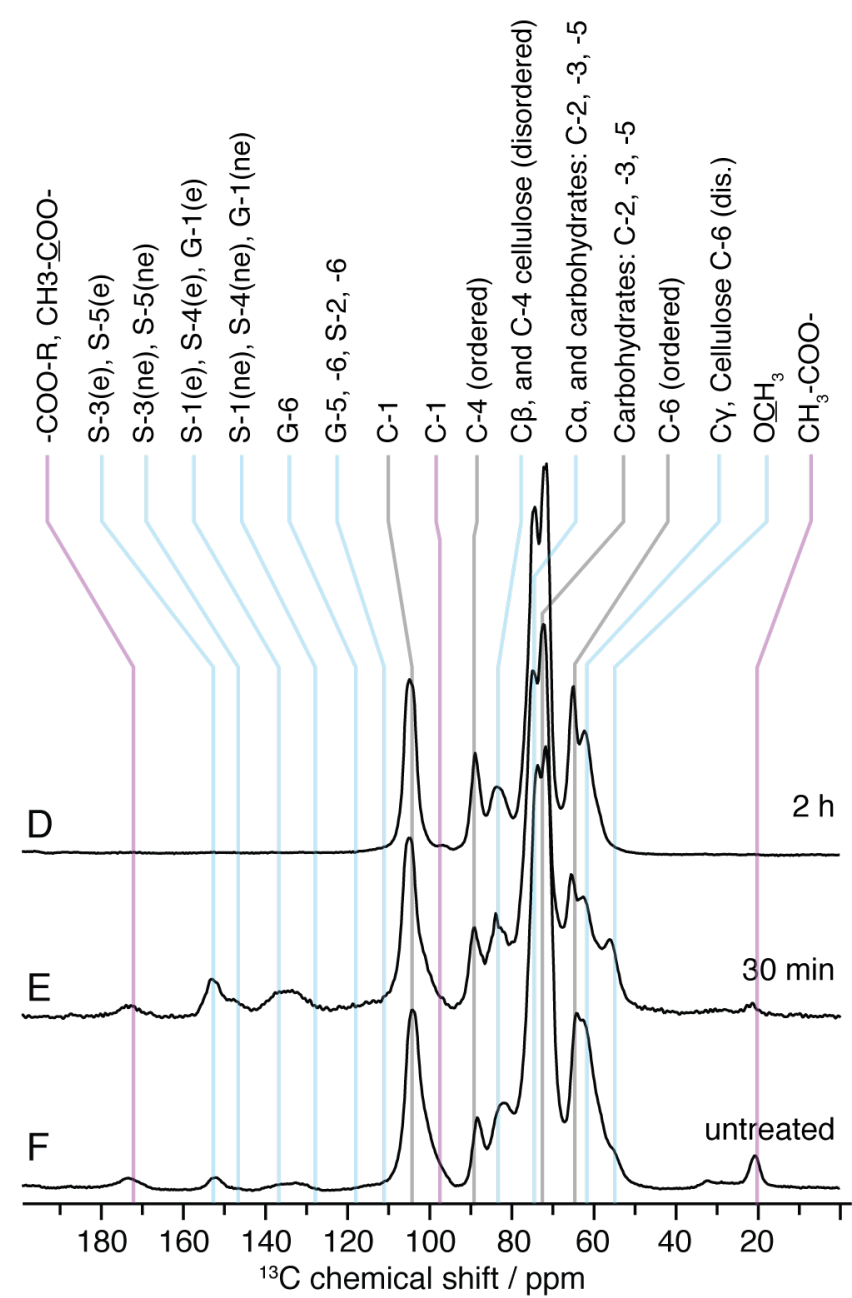

Figure $2 .{ }^{13} \mathrm{C}$ CPMAS DNP enhanced spectra of poplar wood treated with dioxane $/ \mathrm{H}_{2} \mathrm{O} /$ formaldehyde $/ \mathrm{HCl}$ for 2 hours (D) or 30 min (E), and untreated poplar wood $(\mathrm{F})$, all impregnated with 10 $\mathrm{mM}$ AMUPol in $\mathrm{D}_{2} \mathrm{O} / \mathrm{H}_{2} \mathrm{O}(9 / 1 \mathrm{v} / \mathrm{v})$, where the spectra shown in the figure are normalized with respect to the intensity of the $\mathrm{C} 1$ peak of celluloses. The acquisition parameters for the spectra are as follows: spinning rate of $12.5 \mathrm{kHz}$, recycle delay of $3 \mathrm{~s}$ and contact time of $1 \mathrm{~ms}$, number of scans of 256 (D, F), 1024 (E). Refer to Figure 1 for information on the color code and abbreviations.

On the basis of the assignments made previously, the interpretation of the changes observed in Figure 2 is straightforward. After two hours of full treatment, we observe complete disappearance of both lignins and hemicelluloses (see Figure 2D). Note that for the residual celluloses the crystalline moiety is dominant as indicated by the signals assigned to $\mathrm{C} 4$ of crystalline and amorphous celluloses, respectively. There is no evidence of aromatic carbons. This means that in the part of the fibers of wood treated for 2 hours which are accessible to DNP, the delignification can be considered almost complete. In contrast, when the pretreatment time was $30 \mathrm{~min}$, the percentage of lignin appeared to increase within the solid residue as shown by the higher relative intensity of the lignin peaks (see Figure 2E). This increase could be explained by a biomass deconstruction mechanism where, in the initial $30 \mathrm{~min}$ of pretreatment, hemicellulose was the first to be removed while most of the lignin remained within the biomass matrix. 


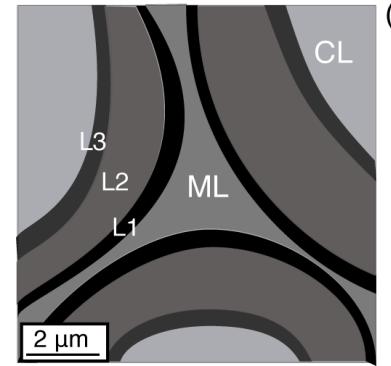

(a)

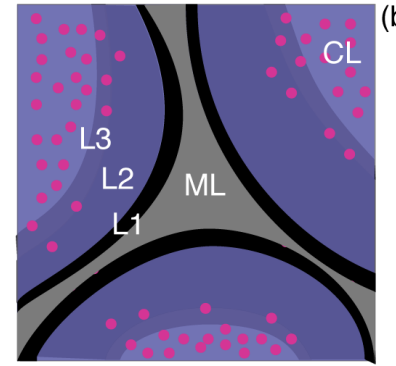

Scheme 2. Scheme of a transverse section of the wood cell wall at the $\mu \mathrm{m}$ scale (a) dry and (b) impregnated with radical solution (blue region) of AMUPol (pink circles) which depicts the cell lumen (CL) at the exterior of the cell walls, and the secondary cell wall layers (L3, L2 and L1). The radical solution should not reach the interior of the cell wall where the middle lamella (ML) is located.

Furthermore, MAS DNP methods permit topological information about the depolymerisation process to be obtained. In order to verify whether or not any residual lignin was still present inside the secondary layers of the cell wall, in particular in the deeper regions such as L1 and the middle lamella, the conventional ${ }^{13} \mathrm{C}$ CPMAS NMR spectrum of the sample of wood after full treatment for a period of 2 hours, was recorded with 35650 scans, and compared with a DNP enhanced spectrum recorded with 256 scans in Figure 3. The short broad peaks present at $130-160 \mathrm{ppm}$ in the conventional spectrum indicated that small quantities of lignin remained within the solid residue. Whereas with the DNP enhanced spectrum, the aromatic region was quite clean, indicating almost no lignin was detected. This unambiguously indicates that the residual lignin is located in the interior of the cell wall, far from the DNP polarizing agent. A comparison of the signals intensities of residual D and G confirms that a very small amount of residual lignin (less that $4 \%$ of the total amount of carbon) remained inside the fiber.

3.3. Input of DNP regioselectivity to cell wall. Figures 1 and $\mathrm{S} 1$ shows that the SNR of lignins (signals S-3(e), S-5(e) and S-1(e), S-4(e), G-1(e)) and hemicelluloses (- $\mathrm{COO}-\mathrm{R}, \mathrm{CH}_{3}-\mathrm{COO}-$ and $\mathrm{CH}_{3}$-COO-) decreases when impregnated with the radical solution (spectrum $\mathrm{C}, \mathrm{NO}$ microwave irradiation) compared to the SSNMR spectrum B. The simplest explanation could be that lignins and hemicelluloses are more accessible to the biradical and that the signal is attenuated by bleaching effects.

Relaxation DNP experiments are used to determine the depolymerization process and to identify the components that remain inside the cell wall (see SI for more details). Summarized in Table 1 are the experimental ${ }^{1} \mathrm{H}$ spin-lattice relaxation $\left(T_{1}\right)$ and in Table S4 their corresponding diffusion lengths $\left(\rho_{t}=\left(D_{t} T_{1}\right)^{1 / 2}\right)$ for treated and untreated (with or without dioxane) wood as determined from measurements of $T_{1}$, and assuming a constant spin diffusion coefficient $\left(D_{t}\right)$ of $10^{-3} \mathrm{~mm}^{2} \cdot \mathrm{s}^{-1}$.

The characteristic $T_{1}$ is longer for treated materials than for pristine wood which could be a consequence of the change in dynamics in the materials. If we consider the NMR signals assigned to the cellulose moiety, all the lengths range between 80 to $130 \mathrm{~nm}$ for the treated and untreated samples (see Table in SI). The $80-130 \mathrm{~nm}$ range of diffusion lengths is clearly shorter than the total thickness expected for a lignocellulosic cell wall of wood materials which is on the order of 4 to $10 \mu \mathrm{m},{ }^{84-86}$, illustrating that the hyperpolarisation probes the surface of the cell walls. This confirms that MAS DNP enhances the secondary cell wall layers and allows a regioselective study of wood material. This near surface characterization is of high relevance when working with chemical processes which are dependent upon the accessibility of the components involved in the process.

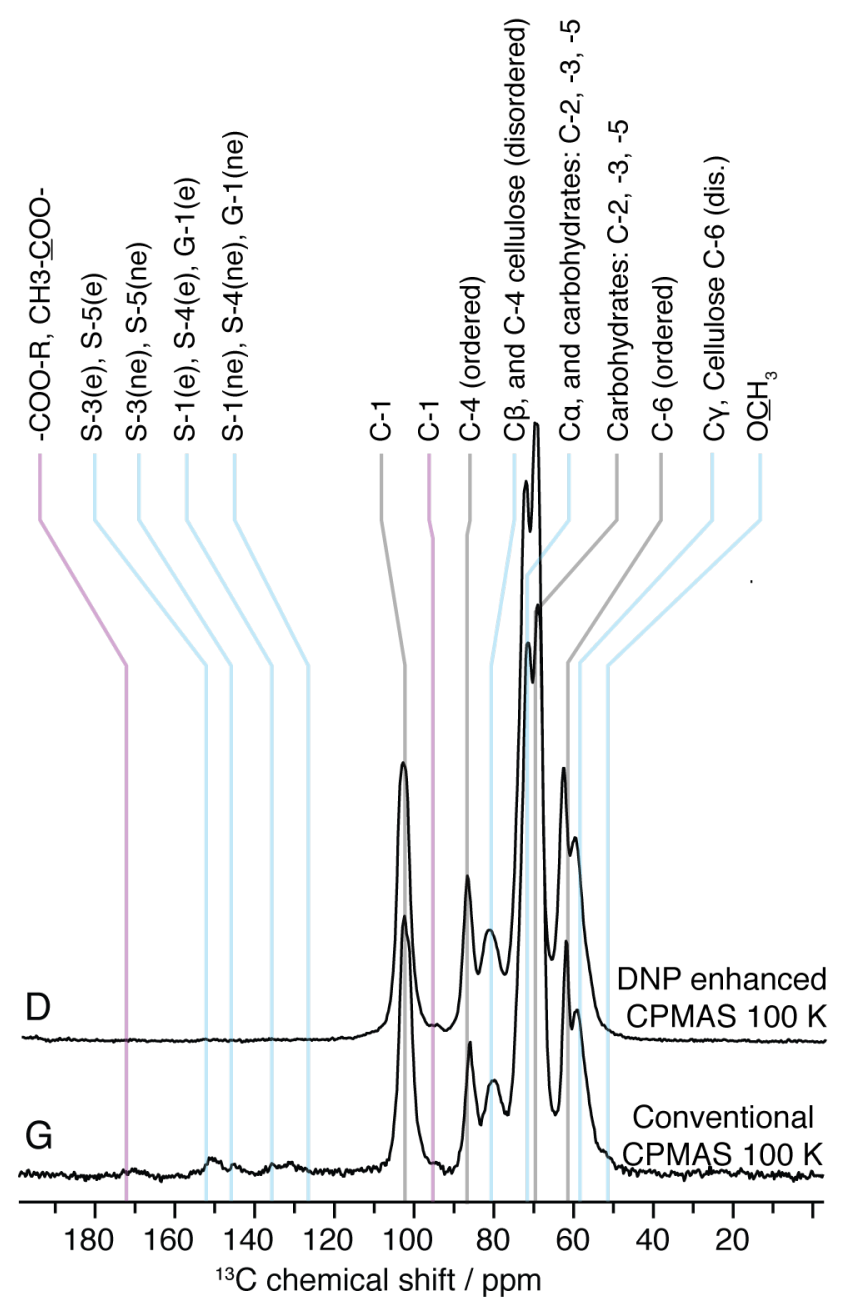

Figure 3. ${ }^{13} \mathrm{C}$ CPMAS NMR spectra acquired at $100 \mathrm{~K}$ of poplar wood treated with $\mathrm{HCl}$ for 2 hours. Spectra are recorded at a spinning rate of $12500 \mathrm{~Hz}$, recycle delay 3s, contact time $1 \mathrm{~ms}$. (D) DNP enhanced CPMAS NMR spectrum, sample impregnated with $10 \mathrm{mM}$ AMUPol in $\mathrm{D}_{2} \mathrm{O} / \mathrm{H}_{2} \mathrm{O}(9 / 1 \mathrm{v} / \mathrm{v}), 256$ scans, and $(\mathrm{G})$ conventional CPMAS NMR spectrum with 35650 scans. The spectra are normalized with respect to the intensity of the $\mathrm{C} 1$ of celluloses. Refer to Figure 1 for information on the color code and abbreviations.

As a result, direct interaction between lignins or hemicelluloses and AMUPol can be discarded, as these components are known to be more abundant in the deepest parts of the cell wall. Therefore the apparent loss of lignins and hemicelluloses observed above is due to the fact that the inner part of the cell wall, the middle lamella, is not observed by MAS DNP (see scheme 2 ). 
Table 1. Measured ${ }^{1} \mathrm{H}$ spin lattice relaxation $T_{1}(\mathrm{~s})$ at 100 $K$ (dry sample) and for wood samples of non-treated and treated wood (full treatment with and without dioxane).

\begin{tabular}{cccccc}
\hline & $\begin{array}{c}\text { Non- } \\
\text { treated }\end{array}$ & \multicolumn{4}{c}{ Treated $80^{\circ} \mathrm{C}$} \\
& 0.5 & $2 \mathrm{~h}$ & $1 \mathrm{~h}$ & $2 \mathrm{~h}$ \\
\hline Lignin & 6.5 & 7.7 & $\mathrm{ND}$ & 0.85 & 1.3 \\
$\begin{array}{c}\text { Cellulose } \\
\text { Hemicel- } \\
\text { lulose }\end{array}$ & 7.5 & 17.3 & 13.1 & 2.6 & 3.3 \\
\hline
\end{tabular}

ND: not determined because signal intensities were too weak.

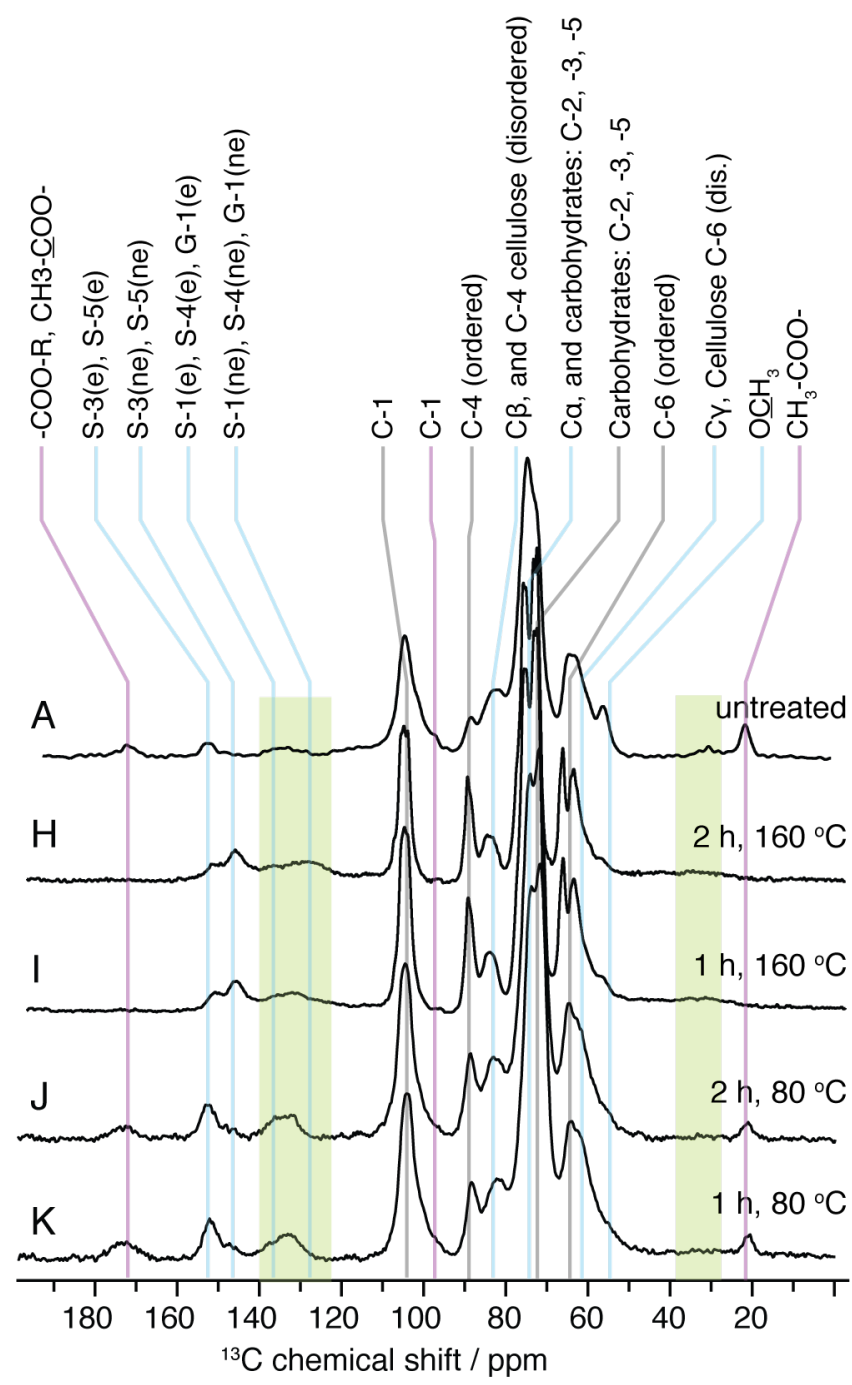

Figure $4 .{ }^{13} \mathrm{C}$ DNP enhanced CPMAS NMR spectra of poplar wood treated with the standard process $(\mathrm{HCl})$ but without dioxane, acquired with a spinning rate of $12500 \mathrm{~Hz}$, recycle delays 3s, contact time of $1 \mathrm{~ms}$. Samples treated for $(\mathrm{H}) 2$ hours at $160{ }^{\circ} \mathrm{C}, 128$ scans 128; (I) 1 hour at $160^{\circ} \mathrm{C}, 128$ scans; (J) 2 hours at $80{ }^{\circ} \mathrm{C}, 4$ scans; $(\mathrm{K}) 1$ hour at $80^{\circ} \mathrm{C}, 4$ scans. The spectra are normalized with respect to the intensity of the $\mathrm{C} 1$ of celluloses. Refer to Figure 1 for information on the color code and abbreviations.

3.4 Role of dioxane. Figure 4 and S2 shows the spectra of the residues after being treated with an acidic aqueous solution (without dioxane) at different times and temperatures. The absence of dioxane leads to a strong accumulation of lignin in the cell lumen of the exterior cell wall. Several conclusions can be drawn by comparing the lignin signals with those of the untreated wood (Figure 1A).

First, it appears that syringyl signal $-3(n e),-5(n e)$ and guaiacyls $-3(n e, e),-4(n e, e)$ strongly increase as the temperature increases from 80 to $160{ }^{\circ} \mathrm{C}$. This indicates that the lignin was depolymerized, recondensed and relocated on the surface of the fibres. These observations are consistent with an initial depolymerization of lignin, with $\beta-\mathrm{O}-4$ cleavage, and subsequent repolymerization of said lignin on the surface of pretreated biomass, consistent with several literature reports. ${ }^{87,} 88$ Moreover, for the wood treated at $160^{\circ} \mathrm{C}$, either for one or two hours, we observe depletion of acetyl groups and a new shoulder at $128 \mathrm{ppm}$ and a broad signal centred at $33 \mathrm{ppm}$, which are not detectable in the samples treated at $80^{\circ} \mathrm{C}$. These signals are highlighted in green in Figure 4. Baccile et al. have assigned signals in this region to furan rings arising from the degradation of carbohydrates in the presence of water ${ }^{89}$ A possible explanation is that, the carbohydrates (mainly hemicellulose in this case) were depolymerized under the acidic condition and partially converted into furans, which further condensed to humins on the cellulose surface. Due to the aforementioned regioselectivity of MAS DNP, we determine that the degradation products are formed within a $40 \mathrm{~nm}$ region from cell lumen and we can conclude that they correspond mainly to products that remain at the surface of the cell wall due to their insolubility in the absence of dioxane. In contrast, the spectrum of the sample pretreated with dioxane $/ \mathrm{HCl} / \mathrm{H}_{2} \mathrm{O} /$ formaldehyde showed only peaks associated with carbohydrates. Thus, dioxane appears to greatly facilitate solubilization of lignin and hemicellulose derivatives during extraction, which prevents their reprecipitation on the surface. These controls were also run without formaldehyde which has also been shown to prevent condensation for both lignin and carbohydrates,${ }^{5} 90$ which likely further contributed to the absence of these residue signals when it was used.

3.5. Reaction of formaldehyde on the surface of cellulose. In order to gain a better understanding of the reactions between formaldehyde and biomass during lignin extraction we used the ${ }^{13} \mathrm{C}$ labelled formaldehyde for the reaction and characterized the leftover solid after delignification to determine if the formaldehyde had reacted with any of the polysaccharide functionalities on the surface. With unlabelled formaldehyde (Figure $5 \mathrm{~N}$ ), no new ${ }^{13} \mathrm{C}$ NMR signals could indicate the occurrence of new structures between residual cellulose and formaldehyde, or selfpolymerization, could be observed. Note that even under MAS DNP conditions no new signal were detected after 64 scans.

On the contrary, in the spectrum of Figure $5 \mathrm{M}$ of the material obtained using fully carbon-13 labelled formaldehyde we clearly see new signals in the spectral range from 100 to 90 ppm, and no significant changes in the cellulose resonances. They can be assigned to $\mathrm{CH}_{2}$ in poly(oxymethylene) structures, as a result of self-polymerization of $\mathrm{CH}_{2} \mathrm{O}$ inside the network 
of the remaining cell wall. Either way, the presence of this material at the surface explains the low activity that was previously observed during enzymatic hydrolysis of formaldehyde treated material. Either self-polymerized or covalently linked formaldehyde at the cellulose surface would block enzyme binding and reaction sites, which would lower hydrolysis activity.

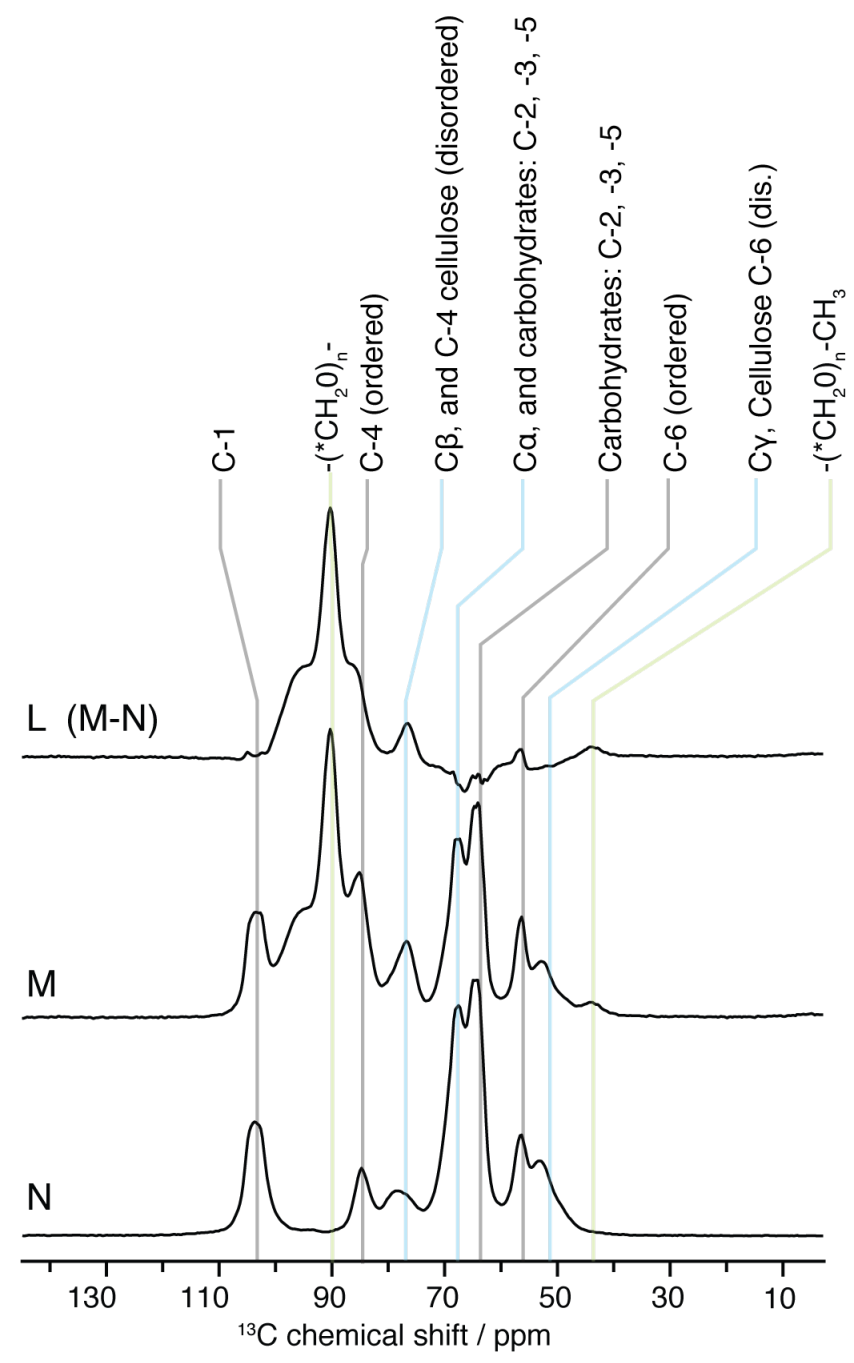

Figure 5. ${ }^{13} \mathrm{C}$ CPMAS DNP enhanced NMR spectra of poplar wood treated with the standard process of $\mathrm{HCl}$ for a period of 2 hours at $80^{\circ} \mathrm{C}$ using (M) labelled ${ }^{13} \mathrm{C}$ formaldehyde and $(\mathrm{N})$ unlabelled ${ }^{13} \mathrm{C}$ formaldehyde. (L) is the difference spectrum between (M)and (N). All spectra recorded with a spinning rate of $12500 \mathrm{~Hz}$, a recycle delays of $3 \mathrm{~s}$, contact time of $2.5 \mathrm{~ms}$, and 64 scans. Refer to Figure 1 for information on the color code and abbreviations.

The solid residue is mainly made of cellulose since lignins and hemicelluloses were almost completely depleted during extraction and dissolution in dioxane. The experiment using fully labelled ${ }^{13} \mathrm{C}$ formaldehyde permits to quantify the amount of new structure formed with respect to the unlabelled sample. By comparison of the integral regions of the formaldehyde with respect to the integral of $\mathrm{C} 1$ of cellulose (see spectrum in Figure S3) we obtained a ratio of $0.8 \mathrm{CHO}$ per glucose unit. If we consider that formaldehyde is fully labelled $(100 \%)$ the ratio has to be divided by the same factor to obtain a molar concentration of $\mathrm{CHO}$ per glucose units. It means that the sensitivity of NMR, even with DNP enhancement, remains in the range of 1 per cent, within the corresponding surface. The depth of the considered surface corresponds to the diffusion distance. Considering the sample treated at $80^{\circ} \mathrm{C}$ during 2 hours which only shows celluloses signals (see spectrum D, Figure 2), the diffusion distance is equal to $\backsim 60 \mathrm{~nm}$, which represents a depth of about 6 cellulose fibrils if we consider a cellulose fibril width of about 10 nm.

\section{CONCLUSIONS}

The high sensitivity of MAS DNP permits acquisition of ${ }^{13} \mathrm{C}$ solid-state NMR spectra in minutes. The carbon chemical shifts are good probes to distinguish between the various constituents of the poplar wood such as celluloses, hemicelluloses and lignins. We have shown how MAS DNP methods allow the study of the topology resulting from pretreatment and fractionation processes of poplar wood where it clearly distinguishes between different sections of the wood cell wall. For example, lignin and hemicelluloses in poplar wood were almost completely extracted after a two-hour pretreatment with dioxane $/ \mathrm{H}_{2} \mathrm{O} /$ formaldehyde/ $\mathrm{HCl}$ according to the ${ }^{13} \mathrm{C}$ CPMAS spectrum. Shorter pretreatment process times of $30 \mathrm{~min}$ do not completely delignify poplar wood, as their residual signals are clearly observed in the ${ }^{13} \mathrm{C}$ CPMAS DNP enhanced NMR spectrum, but not in the conventional NMR spectrum. Hence, MAS DNP is a regioselective method to study wood materials. We show that polarization is effective in a $100 \mathrm{~nm}$ range for these wood materials.

We demonstrate that condensed lignins and humins which reprecipitated in the absence of dioxane and formaldehyde accumulated in a $40 \mathrm{~nm}$ external range of the cell wall. Finally, using fully enriched formaldehyde to follow the depolymerisation mechanism with ${ }^{13} \mathrm{C}$ CPMAS NMR, we have demonstrated that $1 \%$ of the total amount of carbon on the surface of the material could be assigned to self-polymerization of the formaldehyde, which could explain previously observed reductions in cellulose digestibility by surface blockage.

\section{ASSOCIATED CONTENT}

\section{Supporting Information}

The Supporting Information is available free of charge on the ACS Publications website.

Additional experimental details can be found concerning: DNP enhanced NMR spectra, build-up curves, and numerical spin diffusion simulations (PDF).

\section{AUTHOR INFORMATION}

\section{Corresponding Author}

*J.L.: e-mail, jeremy.luterbacher@epfl.ch; phone, +41 (0) 21693 5982.

* M.B.: e-mail, michel.bardet@cea.fr; phone, 33 (0)4 388757 72; fax, $+33(0) 438875090$.

\section{Author Contributions}

The manuscript was written through contributions of all authors. All authors have given approval to the final version of the manuscript. 


\section{Notes}

The authors declare no competing financial interest.

\section{ACKNOWLEDGMENT}

MB was supported by an Outgoing CEA fellowship from the CEAEnhanced Eurotalents program, co-funded by FP7 Marie-Skłodowska-Curie COFUND program (Grant Agreement 600382). This work was also supported by the Swiss Competence Center for Energy Research: Biomass for a Swiss Energy Future through the Swiss Commission for Technology and Innovation grant KTI.2014.0116 as well as EPFL.

\section{ABBREVIATIONS}

DNP SENS, dynamic nuclear polarization surface enhanced spectroscopy; NMR, nuclear magnetic resonance; MAS, magic angle spinning; CP, cross polarization; Syringyls (S); Guaiacyls (G); ne, non-etherified arylglycerol $\beta$-aryl ethers; e, etherified arylglycerol $\beta$-aryl ethers.

\section{REFERENCES}

(1) Sakellariou, P.; Rowe, R. C., Interactions in Cellulose Derivative Films for Oral-Drug Delivery. Prog. Polym. Sci. 1995, 20, 889-942.

(2) Klemm, D.; Heublein, B.; Fink, H. P.; Bohn, A., Cellulose: Fascinating Biopolymer and Sustainable Raw Material. Angew. Chem. Int. Ed. 2005, 44, 3358-3393.

(3) Moon, R. J.; Martini, A.; Nairn, J.; Simonsen, J.; Youngblood, J., Cellulose Nanomaterials Review: Structure, Properties and Nanocomposites. Chem. Soc. Rev. 2005, 40, 3941-3994.

(4) Zhu, H.; Luo, W.; Ciesielski, P. N.; Fang, Z.; Zhu, J. Y.; Henriksson, G.; Himmel, M. E.; Hu, L., Wood-Derived Materials for Green Electronics, Biological Devices, and Energy Applications. Chem. Rev. 2016, 116, 9305-74.

(5) Shuai, L.; Amiri, M. T.; Questell-Santiago, Y. M.; Héroguel, F.; Li, Y.; Kim, H.; Meilan, R.; Chapple, C.; Ralph, J.; Luterbacher, J. S., Formaldehyde Stabilization Facilitates Lignin Monomer Production During Biomass Depolymerization. Science 2016, 354, 329-333.

(6) Lan, W.; Amiri, M. T.; Hunston, C. M.; Luterbacher, J. S., Protection Group Effects During Alpha,Gamma-Diol Lignin Stabilization Promote High-Selectivity Monomer Production. Angew. Chem. Int. Ed. Engl. 2018, 57, 1356-1360.

(7) Talebi Amiri, M.; Dick, G. R.; Questell-Santiago, Y. M.; Luterbacher, J. S., Fractionation of Lignocellulosic Biomass to Produce Uncondensed Aldehyde-Stabilized Lignin. Nature Protocols 2019, 14, 921-954.

(8) Bardet, M.; Gagnaire, D.; Nardin, R.; Robert, D.; Vincendon, M., Use of C-13 Enriched Wood for Structural Nmr Investigation of Wood and Wood Components, Cellulose and Lignins, in Solid and Liquid. Holzforschung 1986, 40,suppl., 17-24.

(9) Gil, A. M.; Neto, C. P., Solid-State Nmr Studies of Wood and Other Lignocellulosic Materials. In Annual Reports on $\mathrm{Nmr}$ Spectroscopy, Vol 37, 1999; Vol. 37, pp 75-117.

(10) Melkior, T.; Jacob, S.; Gerbaud, G.; Hediger, S.; Le Pape, L.; Bonnefois, L.; Bardet, M., Nmr Analysis of the Transformation of Wood Constituents by Torrefaction. Fuel 2012, 92, 271-280.

(11) Cheng, K.; Sorek, H.; Zimmermann, H.; Wemmer, D. E.; Pauly, M., Solution-State 2d Nmr Spectroscopy of Plant Cell Walls Enabled by a Dimethylsulfoxide-D6/1-Ethyl-3-Methylimidazolium Acetate Solvent. Anal. Chem. 2013, 85, 3213-21.

(12) Terashima, N.; Kitano, K.; Kojima, M.; Yoshida, M.; Yamamoto, H.; Westermark, U., Nanostructural Assembly of Cellulose, Hemicellulose, and Lignin in the Middle Layer of Secondary Wall of Ginkgo Tracheid. Journal of Wood Science 2009, 55, 409-416.

(13) Yelle, D. J.; Ralph, J.; Frihart, C. R., Characterization of Nonderivatized Plant Cell Walls Using High-Resolution Solution-State Nmr Spectroscopy. Magn. Reson. Chem. 2008, 46, 508-517.
(14) Mansfield, S. D.; Kim, H.; Lu, F.; Ralph, J., Whole Plant Cell Wall Characterization Using Solution-State 2d Nmr. Nat Protoc 2012, 7, 1579-89.

(15) Kim, H.; Ralph, J., A Gel-State 2d-Nmr Method for Plant Cell Wall Profiling and Analysis: A Model Study with the Amorphous Cellulose and Xylan from Ball-Milled Cotton Linters. RSC Advances 2014, 4, 7549-7560.

(16) Kim, H.; Ralph, J., Solution-State 2d Nmr of Ball-Milled Plant Cell Wall Gels in Dmso-D6/Pyridine-D5. Organic \& Biomolecular Chemistry 2010, 8, 576-591.

(17) Bardet, M.; Gerbaud, G.; Doan, C.; Giffard, M.; Hediger, S.; De Paepe, G.; Tran, Q. K., Dynamics Property Recovery of Archaeological-Wood Fibers Treated with Polyethylene Glycol Demonstrated by High-Resolution Solid-State Nmr. Cellulose 2012, 19, 1537-1545.

(18) Simmons, T. J.; Mortimer, J. C.; Bernardinelli, O. D.; Poppler, A. C.; Brown, S. P.; Deazevedo, E. R.; Dupree, R.; Dupree, P., Folding of Xylan onto Cellulose Fibrils in Plant Cell Walls Revealed by Solid-State Nmr. Nat. Commun. 2016, 7.

(19) Kang, X.; Kirui, A.; Dickwella Widanage, M. C.; MentinkVigier, F.; Cosgrove, D. J.; Wang, T., Lignin-Polysaccharide Interactions in Plant Secondary Cell Walls Revealed by Solid-State Nmr. Nat Commun 2019, 10, 347.

(20) Grantham, N. J., et al., An Even Pattern of Xylan Substitution Is Critical for Interaction with Cellulose in Plant Cell Walls. Nature Plants 2017, 3, 859-865.

(21) Dupree, R.; Simmons, T. J.; Mortimer, J. C.; Patel, D.; Iuga, D.; Brown, S. P.; Dupree, P., Probing the Molecular Architecture of Arabidopsis Thaliana Secondary Cell Walls Using Two- and ThreeDimensional (13)C Solid State Nuclear Magnetic Resonance Spectroscopy. Biochemistry 2015, 54, 2335-45.

(22) Wickholm, K.; Larson, P. T.; Iversen, T., Assignment of Non-Crystalline Forms in Cellulose I by $\mathrm{Cp} / \mathrm{Mas} 13 \mathrm{c} \mathrm{Nmr}$ Spectroscopy. Carbohydr. Res. 1998, 312, 123-129.

(23) Atalla, R. H.; VanderHart, D. L., The Role of Solid State 13c $\mathrm{Nmr}$ Spectroscopy in Studies of the Nature of Native Cellulose. Solid State Nucl. Magn. Reson. 1999, 15, 1-19.

(24) Dick-Perez, M.; Zhang, Y.; Hayes, J.; Salazar, A.; Zabotina, O. A.; Hong, M., Structure and Interactions of Plant Cell-Wall Polysaccharides by Two- and Three-Dimensional Magic-AngleSpinning Solid-State Nmr. Biochemistry 2011, 50, 989-1000.

(25) Foston, M., Advances in Solid-State Nmr of Cellulose. Curr. Opin. Biotechnol. 2014, 27, 176-84.

(26) Masuda, K.; Adachi, M.; Hirai, A.; Yamamoto, H.; Kaji, H.; Horii, F., Solid-State $13 \mathrm{c}$ and $1 \mathrm{~h}$ Spin Diffusion Nmr Analyses of the Microfibril Structure for Bacterial Cellulose. Solid State Nucl. Magn. Reson. 2003, 23, 198-212.

(27) Ni, Q. Z.; Daviso, E.; Can, T. V.; Markhasin, T. M.; Temkin, R. J.; Herzfeld, J.; Griffin, R. G., High Frequency Dynamic Nuclear Polarization. Acc. Chem. Res. 2013, 46, 1933-1941.

(28) Rossini, A. J.; Zagdoun, A.; Lelli, M.; Lesage, A.; Copéret, C.; Emsley, L., Dynamic Nuclear Polarization Surface Enhanced Nmr Spectroscopy. Acc. Chem. Res. 2013, 46, 1942-1951.

(29) Lesage, A., et al., Surface Enhanced Nmr Spectroscopy by Dynamic Nuclear Polarization. J. Am. Chem. Soc. 2010, 132, 1545915461.

(30) Love, A. M., et al., Probing the Transformation of Boron Nitride Catalysts under Oxidative Dehydrogenation Conditions. J. Am. Chem. Soc. 2018.

(31) Walder, B. J.; Berk, C.; Liao, W. C.; Rossini, A. J.; Schwarzwalder, M.; Pradere, U.; Hall, J.; Lesage, A.; Coperet, C.; Emsley, L., One- and Two-Dimensional High-Resolution Nmr from Flat Surfaces. ACS Cent Sci 2019, 5, 515-523.

(32) Piveteau, L., et al., Resolving the Core and the Surface of Cdse Quantum Dots and Nanoplatelets Using Dynamic Nuclear Polarization Enhanced Pass-Pieta Nmr Spectroscopy. ACS Central Science 2018.

(33) Hope, M. A.; Halat, D. M.; Magusin, P. C.; Paul, S.; Peng, L.; Grey, C. P., Surface-Selective Direct 17o Dnp Nmr of Ceo2 Nanoparticles. Chem. Commun. 2017, 53, 2142-2145. 
(34) Wolf, T.; Kumar, S.; Singh, H.; Chakrabarty, T.; Aussenac, F.; Frenkel, A. I.; Major, D. T.; Leskes, M., Endogenous Dynamic Nuclear Polarization for Natural Abundance $17 \mathrm{o}$ and Lithium Nmr in the Bulk of Inorganic Solids. J. Am. Chem. Soc. 2018.

(35) Mais, M.; Torroba, J.; Barrow, N. S.; Paul, S.; Titman, J. J., Ion Exchange and Binding in Selenium Remediation Materials Using Dnp-Enhanced Solid-State Nmr Spectroscopy. Solid State Nucl. Magn. Reson. 2019, 98, 19-23.

(36) Bjorgvinsdottir, S.; Walder, B. J.; Pinon, A. C.; Emsley, L., Bulk Nuclear Hyperpolarization of Inorganic Solids by Relay from the Surface. J. Am. Chem. Soc. 2018, 140, 7946-7951.

(37) Pump, E., et al., Predicting the Dnp-Sens Efficiency in Reactive Heterogeneous Catalysts from Hydrophilicity. Chem. Sci. 2018, 9, 4866-4872.

(38) Kobayashi, T.; Perras, F. A.; Slowing, I. I.; Sadow, A. D.; Pruski, M., Dynamic Nuclear Polarization Solid-State Nmr in Heterogeneous Catalysis Research. ACS Catalysis 2015, 5, 7055-7062.

(39) Rankin, A. G. M.; Webb, P. B.; Dawson, D. M.; VigerGravel, J.; Walder, B. J.; Emsley, L.; Ashbrook, S. E., Determining the Surface Structure of Silicated Alumina Catalysts Via Isotopic Enrichment and Dynamic Nuclear Polarization Surface-Enhanced Nmr Spectroscopy. J. Phys. Chem C. 2017, 121, 22977-22984.

(40) Moroz, I. B.; Larmier, K.; Liao, W.-C.; Copéret, C., Discerning $\Gamma$-Alumina Surface Sites with Nitrogen-15 Dynamic Nuclear Polarization Surface Enhanced Nmr Spectroscopy of Adsorbed Pyridine. J. Phys. Chem C. 2018, 122, 10871-10882.

(41) Leskes, M.; Kim, G.; Liu, T.; Michan, A. L.; Aussenac, F.; Dorffer, P.; Paul, S.; Grey, C. P., Surface-Sensitive Nmr Detection of the Solid Electrolyte Interphase Layer on Reduced Graphene Oxide. $J$ Phys. Chem. Lett. 2017, 8, 1078-1085.

(42) Berruyer, P.; Lelli, M.; Conley, M. P.; Silverio, D. L.; Widdifield, C. M.; Siddiqi, G.; Gajan, D.; Lesage, A.; Coperet, C.; Emsley, L., Three-Dimensional Structure Determination of Surface Sites. J. Am. Chem. Soc. 2017, 139, 849-855.

(43) Kumar, A.; Walder, B. J.; Kunhi Mohamed, A.; Hofstetter, A.; Srinivasan, B.; Rossini, A. J.; Scrivener, K.; Emsley, L.; Bowen, P., The Atomic-Level Structure of Cementitious Calcium Silicate Hydrate. J. Phys. Chem C. 2017, 121, 17188-17196.

(44) Sangodkar, R. P.; Smith, B. J.; Gajan, D.; Rossini, A. J.; Roberts, L. R.; Funkhouser, G. P.; Lesage, A.; Emsley, L.; Chmelka, B. F., Influences of Dilute Organic Adsorbates on the Hydration of Low-Surface-Area Silicates. J. Am. Chem. Soc. 2015, 137, 8096-112.

(45) Ouari, O.; Phan, T.; Ziarelli, F.; Casano, G.; Aussenac, F.; Thureau, P.; Gigmes, D.; Tordo, P.; Viel, S., Improved Structural Elucidation of Synthetic Polymers by Dynamic Nuclear Polarization Solid-State Nmr Spectroscopy. ACS Macro Letters 2013, 2, 715-719.

(46) Mollica, G., et al., Observing Apparent Nonuniform Sensitivity Enhancements in Dynamic Nuclear Polarization Solid-State Nmr Spectra of Polymers. ACS Macro Letters 2014, 3, 922-925.

(47) Le, D., et al., Optimizing Sample Preparation Methods for Dynamic Nuclear Polarization Solid-State Nmr of Synthetic Polymers. Macromol. 2014, 47, 3909-3916.

(48) Verde-Sesto, E.; Goujon, N.; Sardon, H.; Ruiz, P.; Huynh, T. V.; Elizalde, F.; Mecerreyes, D.; Forsyth, M.; O’Dell, L. A., Dnp Nmr Studies of Crystalline Polymer Domains by Copolymerization with Nitroxide Radical Monomers. Macromol. 2018, 51, 8046-8053.

(49) Schäfer, T.; Vowinkel, S.; Breitzke, H.; Gallei, M.; Gutmann, T., Selective Dnp Signal Amplification to Probe Structures of Core-Shell Polymer Hybrid Nanoparticles. The Journal of Physical Chemistry C 2019, 123, 644-652.

(50) Smith, A. N.; Long, J. R., Dynamic Nuclear Polarization as an Enabling Technology for Solid State Nuclear Magnetic Resonance Spectroscopy. Anal. Chem. 2016, 88, 122-32.

(51) Gupta, R., et al., Dynamic Nuclear Polarization Enhanced Mas Nmr Spectroscopy for Structural Analysis of Hiv-1 Protein Assemblies. J. Phys. Chem. B 2016, 120, 329-39.

(52) Jaudzems, K., et al., Dynamic Nuclear PolarizationEnhanced Biomolecular Nmr Spectroscopy at High Magnetic Field with Fast Magic-Angle Spinning. Angew. Chem. Int. Ed. Engl. 2018, $57,7458-7462$.
(53) Ni, Z. Q.; Daviso, E.; Can, T.; Markahasin, E.; Jawla, S. K.; Swager, T. M.; Temkin, R. J.; Herzfeld, J.; Griffin, R. G., Acc. Chem. Res. 2013, 46, 1933-1941.

(54) Ni, Q. Z.; Can, T. V.; Daviso, E.; Belenky, M.; Griffin, R. G.; Herzfeld, J., Primary Transfer Step in the Light-Driven Ion Pump Bacteriorhodopsin: An Irreversible U-Turn Revealed by Dynamic Nuclear Polarization-Enhanced Magic Angle Spinning Nmr. J. Am. Chem. Soc. 2018, 140, 4085-4091.

(55) Marin-Montesinos, I.; Goyard, D.; Gillon, E.; Renaudet, O.; Imberty, A.; Hediger, S.; De Paëpe, G., Selective High-Resolution Dnp-Enhanced Nmr of Biomolecular Binding Sites. Chem. Sci. 2019.

(56) Ni, Q. Z., et al., In Situ Characterization of Pharmaceutical Formulations by Dynamic Nuclear Polarization Enhanced Mas Nmr. $J$. Phys. Chem. B 2017, 121, 8132-8141.

(57) Hirsh, D. A.; Rossini, A. J.; Emsley, L.; Schurko, R. W., (35)Cl Dynamic Nuclear Polarization Solid-State Nmr of Active Pharmaceutical Ingredients. PCCP 2016, 18, 25893-25904.

(58) Zhao, L.; Hanrahan, M. P.; Chakravarty, P.; DiPasquale, A. G.; Sirois, L. E.; Nagapudi, K.; Lubach, J. W.; Rossini, A. J., Characterization of Pharmaceutical Cocrystals and Salts by Dynamic Nuclear Polarization-Enhanced Solid-State Nmr Spectroscopy. Cryst. Growth Des. 2018, 18, 2588-2601.

(59) Zhao, L.; Pinon, A. C.; Emsley, L.; Rossini, A. J., DnpEnhanced Solid-State Nmr Spectroscopy of Active Pharmaceutical Ingredients. Magn. Reson. Chem. 2018, 56, 583-609.

(60) Takahashi, H.; Lee, D.; Dubois, L.; Bardet, M.; Hediger, S.; De Paepe, G., Rapid Natural-Abundance 2d C-13-C-13 Correlation Spectroscopy Using Dynamic Nuclear Polarization Enhanced SolidState Nmr and Matrix-Free Sample Preparation. Angewandte ChemieInternational Edition 2012, 51, 11766-11769.

(61) Wang, T.; Park, Y. B.; Caporini, M. A.; Rosay, M.; Zhong, L.; Cosgrove, D. J.; Hong, M., Sensitivity-Enhanced Solid-State Nmr Detection of Expansin's Target in Plant Cell Walls. Proc. Natl. Acad. Sci. 2013, 110, 16444-9.

(62) Perras, F. A.; Luo, H.; Zhang, X.; Mosier, N. S.; Pruski, M.; Abu-Omar, M. M., Atomic-Level Structure Characterization of Biomass Pre- and Post-Lignin Treatment by Dynamic Nuclear Polarization-Enhanced Solid-State Nmr. J. Phys. Chem. A 2017, 121, 623-630.

(63) Gutmann, T.; Kumari, B.; Zhao, L.; Breitzke, H.; Schoettner, S.; Ruettiger, C.; Gallei, M., Dynamic Nuclear Polarization Signal Amplification as a Sensitive Probe for Specific Functionalization of Complex Paper Substrates. J. Phys. Chem C. 2017, 121, 3896-3903.

(64) Sauvee, C.; Rosay, M.; Casano, G.; Aussenac, F.; Weber, R. T.; Ouari, O.; Tordo, P., Highly Efficient, Water-Soluble Polarizing Agents for Dynamic Nuclear Polarization at High Frequency. Angew. Chem. Int. Ed. Engl. 2013, 52, 10858-61.

(65) Song, C.; Hu, K.-N.; Joo, C.-G.; Swager, T. M.; Griffin, R. G., Totapol: A Biradical Polarizing Agent for Dynamic Nuclear Polarization Experiments in Aqueous Media. J. Am. Chem. Soc. 2006, $128,11385-11390$.

(66) Kubicki, D. J., et al., Rational Design of Dinitroxide Biradicals for Efficient Cross-Effect Dynamic Nuclear Polarization. Chem. Sci. 2016, 7, 550-558.

(67) Zagdoun, A., et al., Large Molecular Weight Nitroxide Biradicals Providing Efficient Dynamic Nuclear Polarization at Temperatures up to 200 K. J. Am. Chem. Soc. 2013, 135, 12790-12797.

(68) Pines, A.; Gibby, M. G.; Waugh, J. S., Proton - Enhanced Nuclear Induction Spectroscopy. A Method for High Resolution Nmr of Dilute Spins in Solids. The Journal of Chemical Physics 1972, 56, 1776-1777.

(69) Demco, D. E.; Johansson, A.; Tegenfeldt, J., Proton Spin Diffusion for Spatial Heterogeneity and Morphology Investigations of Polymers. Solid State Nucl. Magn. Reson. 1995, 4, 13-38.

(70) Clauss, J.; Schmidt-Rohr, K.; Spiess, H. W., Determination of Domain Sizes in Heterogeneous Polymers by Solid-State Nmr. Acta Polym. 1993, 44, 1-17.

(71) Rossini, A. J.; Widdifield, C. M.; Zagdoun, A.; Lelli, M.; Schwarzwalder, M.; Coperet, C.; Lesage, A.; Emsley, L., Dynamic Nuclear Polarization Enhanced Nmr Spectroscopy for Pharmaceutical Formulations. J. Am. Chem. Soc. 2014, 136, 2324-2334. 
(72) Pinon, A. C., et al., Measuring Nano- to Microstructures from Relayed Dynamic Nuclear Polarization Nmr. J. Phys. Chem C. 2017, 121, 15993-16005.

(73) Schlagnitweit, J.; Tang, M.; Baias, M.; Richardson, S.; Schantz, S.; Emsley, L., Nanostructure of Materials Determined by Relayed Paramagnetic Relaxation Enhancement. J. Am. Chem. Soc. 2015, 137, 12482-12485.

(74) Pinon, A. C.; Skantze, U.; Viger-Gravel, J.; Schantz, S.; Emsley, L., Core-Shell Structure of Organic Crystalline Nanoparticles Determined by Relayed Dynamic Nuclear Polarization Nmr. J. Phys. Chem. A 2018.

(75) Viger-Gravel, J.; Schantz, A.; Pinon, A. C.; Rossini, A. J.; Schantz, S.; Emsley, L., Structure of Lipid Nanoparticles Containing Sirna or Mrna by Dynamic Nuclear Polarization-Enhanced Nmr Spectroscopy. J. Phys. Chem. B 2018, 122, 2073-2081.

(76) Fung, B. M.; Khitrin, A. K.; Ermolaev, K., J. Magn. Reson. 2000, 142, 172-179.

(77) Bardet, M.; Emsley, L.; Vincendon, M., Two-Dimensional Spin-Exchange Solid-State Nmr Studies of C-13-Enriched Wood. Solid State Nucl. Magn. Reson. 1997, 8, 25-32.

(78) Lesage, A.; Bardet, M.; Emsley, L., Through-Bond CarbonCarbon Connectivities in Disordered Solids by Nmr. J. Am. Chem. Soc. 1999, 121, 10987-10993.

(79) Bardet, M.; Hediger, S.; Gerbaud, G.; Gambarelli, S.; Jacquot, J. F.; Foray, M. F.; Gadelle, A., Investigation with C-13 Nmr, Epr and Magnetic Susceptibility Measurements of Char Residues Obtained by Pyrolysis of Biomass. Fuel 2007, 86, 1966-1976.

(80) Melkior, T.; Barthomeuf, C.; Bardet, M., Inputs of SolidState Nmr to Evaluate and Compare Thermal Reactivity of Pine and Beech Woods under Torrefaction Conditions and Modified Atmosphere. Fuel 2017, 187, 250-260.

(81) Bardet, M.; Gerbaud, G.; Giffard, M.; Doan, C.; Hediger, S.; Pape, L. L., 13c High-Resolution Solid-State Nmr for Structural Elucidation of Archaeological Woods. Prog. Nucl. Magn. Reson. Spectrosc. 2009, 55, 199-214.

(82) Lewandowski, J. R.; Halse, M. E.; Blackledge, M.; Emsley, L., Direct Observation of Hierarchical Protein Dynamics. Science 2015, 348, 578-581.
(83) Rossini, A. J.; Zagdoun, A.; Lelli, M.; Gajan, D.; Rascón, F.; Rosay, M.; Maas, W. E.; Copéret, C.; Lesage, A.; Emsley, L., One Hundred Fold Overall Sensitivity Enhancements for Silicon-29 Nmr Spectroscopy of Surfaces by Dynamic Nuclear Polarization with Cpmg Acquisition. Chem. Sci. 2012, 3, 108-115.

(84) Sorieul, M.; Dickson, A.; Hill, S. J.; Pearson, H., Plant Fibre: Molecular Structure and Biomechanical Properties, of a Complex Living Material, Influencing Its Deconstruction Towards a Biobased Composite. Materials 2016, 9.

(85) Fahlen, J.; Salmen, L., Cross-Sectional Structure of the Secondary Wall of Wood Fibers as Affected by Processing. J. Mater. Sci. 2003, 38, 119-126.

(86) Reza, M.; Kontturi, E.; Jaaskelainen, A. S.; Vuorinen, T.; Ruokolainen, J., Transmission Electron Microscopy for Wood and Fiber Analysis - a Review. Bioresources 2015, 10, 6230-6261.

(87) Sedig, M. J.; Viamajala, S.; Decker, S. R.; Tucker, M. P.; Himmel, M. E.; B., V. T., Deposition of Lignin Droplets Produced During Dilute Acid Pretreatment of Maize Stems Retards Enzymatic Hydrolysis of Cellulose

. Biotechnol. Progr. 2007, 23, 1333-1339.

(88) Pielhop, T.; Larrazábal, G. O.; Studer, M. H.; Brethauer, S.; Seidel, C.-M.; Rudolf von Rohr, P., Lignin Repolymerisation in Spruce Autohydrolysis Pretreatment Increases Cellulase Deactivation. Green Chemistry 2015, 17, 3521-3532.

(89) Baccile, N.; Laurent, G.; Babonneau, F.; Fayon, F.; Titirici, M. M.; Antonietti, M., Structural Characterization of Hydrothermal Carbon Spheres by Advanced Solid-State Mas C-13 Nmr Investigations. J. Phys. Chem C. 2009, 113, 9644-9654.

(90) Questell-Santiago, Y. M.; Zambrano-Varela, R.; Talebi Amiri, M.; Luterbacher, J. S., Carbohydrate Stabilization Extends the Kinetic Limits of Chemical Polysaccharide Depolymerization. Nat Chem 2018, 10, 1222-1228.

\section{TOC Graphic}

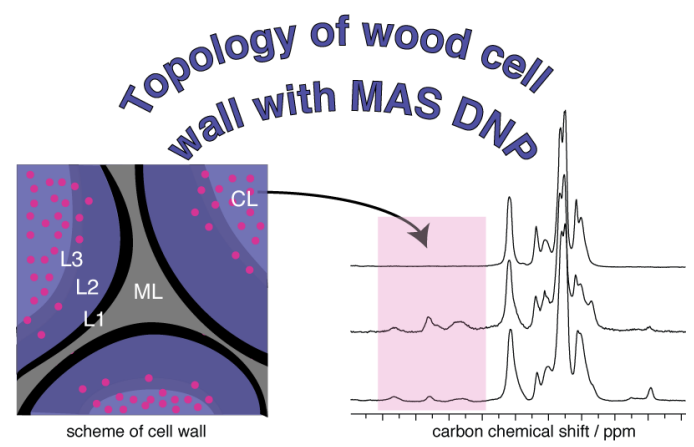

